\title{
PERSEPSI GURU TKI TERHADAP PENDIDIKAN SEKSUAL ANAK USIA DINI BERDASARKAN HEALTH-BELIEF MODEL
}

\author{
Juliette Pepita Felicia dan Weny Savitry S. Pandia \\ Magister Profesi Psikologi Universitas Katolik Indonesia Atma Jaya \\ e-mail: juliette.ildrem@ gmail.com wenv.sembiring@atmajava.ac.id
}

\begin{abstract}
Abstrak
Penelitian ini bertujuan memberikan deskripsi persepsi guru taman kanak-kanak Islam (TKI) terhadap pendidikan seksual anak usia dini berdasarkan teori Health-Belief Model (HBM). Penelitian dilakukan di TKI XYZ menggunakan pendekatan kuantitatif dengan metode kuesioner dan pendekatan kualitatif dengan metode wawancara. HBM mengandung berbagai persepsi individu yang berkaitan dengan perilaku kesehatan. Perilaku kesehatan dalam penelitian ini adalah penerapan pendidikan seksual anak usia dini. Hasil data kuantitatif menunjukkan sebagian besar guru memiliki persepsi netral dalam setiap variabel HBM yaitu $50 \%$ guru pada Perceived Susceptibility, $62.5 \%$ guru pada Perceived Severity, $62.5 \%$ guru pada Perceived Benefit, $68.75 \%$ guru pada Perceived Barrier, $62.5 \%$ guru pada Cues to Action, $81.25 \%$ guru pada Self-Efficacy, dan $56.25 \%$ guru pada Perilaku Kesehatan. Data kualitatif menunjukkan guru TKI XYZ belum melakukan Perilaku Kesehatan secara komprehensif. Informasi terkait pendidikan seksual yang disampaikan pada siswa tidak sistematis, bersifat situasional, belum merata kepada seluruh siswa, dan belum dapat di evaluasi keefektifannya. Hal ini disebabkan pemahaman guru yang kurang mengenai kekerasan seksual, perkembangan seksual, dan pendidikan seksual anak usia dini. Hambatan guru dalam menerapkan Perilaku Kesehatan adalah kemampuan diri, faktor budaya, dan persetujuan orangtua siswa.
\end{abstract}

Kata Kunci: persepsi, guru, health-belief model, pendidikan seksual, anak usia dini

\section{TEACHER'S PERSPECTIVE OF EARLY CHILDHOOD SEXUAL EDUCATION BASED ON HEALTH-BELIEF MODEL}

\begin{abstract}
The study aims is to describe Islamic kindergarten teacher's perspective of early childhood sexual education based on Health-Belief Model (HBM) theory. The methods in this study are quantitative (questionnaire) and qualitative (interview) in XYZ Islamic kindergarten. HBM contains several individual's perceptions that related to health behaviour. Health behaviour in this study is teaching sexual education for early childhood. Quantitative result shows that most of teachers have neutral perceptions on every HBM variables, which is $50 \%$ teachers on Perceived Susceptibility, 62.5\% teachers on Perceived Severity, 62.5\% teachers on Perceived Benefit, $68.75 \%$ teachers on Perceived Barrier, $62.5 \%$ teachers on Cues to Action, $81.25 \%$ teachers on Self-Efficacy, and 56.25\% teachers on Health Behavior. Qualitative result shows $X Y Z$ Islamic kindergarten teachers' have not yet conducted a comprehensive sexual education. Information relating to sexual education delivered to students unsystematically based on situational event, uneven to all students, and cannot be evaluated for effectiveness. This is due to a poor teacher's understanding of sexual violence, sexual development, and sexual education of early childhood. Teachers' barriers in applying Health Behavior are selfability, cultural factors, and parental consent.
\end{abstract}

Keywords: perception, teacher, health-belief model, sexual education, early childhood 


\section{PENDAHULUAN}

Fenomena kekerasan seksual anak usia dini (0-6 tahun) di Indonesia saat ini semakin marak diberitakan di berbagai media. Hal ini menjadi perhatian khusus sejak terjadi kekerasan seksual pada siswa di Jakarta International School (JIS) dan St. Monica beberapa tahun yang lalu. Pada tahun 2017, Polda Metro Jaya membongkar komunitas pedofil (Official Candy's Group) yang memakan korban begitu banyak anak-anak, dengan korban termuda berusia 2 tahun.

Kekerasan seksual pada anak adalah keterlibatan seorang anak, sebelum anak tersebut mencapai usia dewasa yang ditetapkan oleh hukum negara yang bersangkutan, dimana orang dewasa atau anak lain yang usianya lebih tua atau orang yang dianggap memiliki pengetahuan lebih dari anak memanfaatkannya untuk kesenangan seksual atau aktivitas seksual (Maslihah, 2013). Anak-anak termasuk kelompok yang rentan akan kekerasan seksual dan lebih sulit terdeteksi karena tidak semua anak usia dini dapat memahami serta mengungkapkan kekerasan seksual yang dialaminya (Maslihah, 2013). Faktor penyebab anak usia dini rentan akan kekerasan seksual berdasarkan beberapa sumber adalah (1) Fisik anak usia dini kecil dan lebih lemah dibandingkan anak yang lebih besar atau orang dewasa sehingga tidak dapat melawan ketika menjadi korban kekerasan seksual, (2) Anak usia dini tidak berdaya secara psikis (merasa takut) untuk menolak permintaan anak-anak yang lebih tua atau orang dewasa, karena mereka belum mandiri dan masih bergantung pada orang dewasa di sekitarnya, (3) Anak usia dini mudah mempercayai orang lain sehingga mudah diperdaya dengan iming-iming hadiah, (4) Perkembangan kognitif anak usia dini yang meningkat mempengaruhi perkembangan bahasanya menjadi lebih baik, namun mereka tetap belum dapat menceritakan atau mengekspresikan secara detil kejadian yang dialaminya, (5)
Kurangnya kontrol dan kesadaran orang dewasa di sekitarnya dalam mengantisipasi tindak kekerasan seksual (Hastuti, 2014; Justicia, 2015; Humaira, Rohmah, Rifanda, Novitasari, Diena, \& Nuqul, 2015; Hapsari, 2016).

Lingkungan di sekitar anak usia dini memiliki peran untuk mencegah kekerasan seksual yang dapat terjadi. Salah satunya dengan membekali anak pengetahuan, nilai-nilai, sikap, dan keterampilan yang berhubungan dengan anatomi tubuh, hubungan personal, dan seksualitas atau memberikan pendidikan seksual pada anak sejak dini. Peran ini, salah satunya, dapat dipenuhi oleh guru di sekolah karena sekolah merupakan institusi formal profesional yang bisa memberikan pendidikan seksual secara terstruktur dan anak menghabiskan sebagian waktunya di sekolah (WHO, 2010). Sekolah juga merupakan tempat anak bersosialisasi dan berinteraksi dengan orang dewasa lain yang bukan keluarganya sehingga memiliki banyak contoh nyata dalam belajar pendidikan seksual (UNESCO, 2009) serta anak memiliki kepercayaan yang tinggi terhadap guru sebagai orang dewasa lain di lingkungannya (David, dalam Yulianti \& Handayani, 2016).

Alasan lainnya adalah keterbatasan orangtua dalam memberikan pendidikan seksual bagi anak-anaknya karena tidak semua anak berasal dari keluarga dengan pola komunikasi juga interaksi yang hangat dan terbuka untuk membahas seksualitas. Hal ini ditambah dengan berkembang pesatnya PAUD di Indonesia yang terlihat dari meningkatnya kesadaran orangtua memasukkan anakanaknya ke PAUD sehingga peran guru PAUD menjadi penting dalam mewadahi pendidikan seksual bagi anak (Hapsari, 2016). Berdasarkan data dari Direktorat PAUD, jumlah pendidik anak usia dini di Indonesia pun meningkat seiring dengan banyaknya jumlah anak (dalam Christianti, 2012). Oleh karena itu, jika peran guru di sekolah dapat dioptimalkan 
maka kekerasan seksual pada anak dapat diminimalisir seiring dengan meningkatkan kesadaran guru akan pentingnya pendidikan seksual anak usia dini. Hal ini juga berkaitan dengan bagaimana guru mempersepsikan pendidikan seksual bagi siswanya. Persepsi guru menjadi penting karena hasil persepsi terhadap lingkungannya akan mempengaruhi pikiran, perilaku, dan sikap dalam kehidupan sehari-hari (Salkind, 2008)..

Pelaksanaan program pendidikan seksual anak usia dini termasuk dalam melakukan perilaku kesehatan, karena tujuan dari program tersebut salah satunya merupakan tindakan pencegahan terhadap suatu penyakit, baik fisik maupun psikologis. Menurut Conner (2002), perilaku kesehatan adalah suatu tindakan yang diambil dengan tujuan penccegahan/mendeteksi suatu penyakit atau meningkatkan kesehatan dan kesejahteraan. Suatu model teori psikologis yang berkaitan dengan kesehatan, persepsi individu, dan dapat memprediksi perilaku disebut dengan Health-Belief Model atau HBM (Glanz, Rimer, \& Viswanath, 2008).

HBM adalah sekumpulan keyakinan atau persepsi yang mempengaruhi individu untuk menampilkan suatu bentuk perilaku kesehatan (Brewer \& Rimer, 2008). HBM pertama kali dikembangkan tahun 1950 oleh psikolog-psikolog sosial untuk memahami alasan masyarakat tidak menggunakan jasa pencegahan (screening) suatu kondisi penyakit. Sejak itu model ini banyak sekali diadaptasi untuk mengeksplorasi variasi perilaku kesehatan jangka pendek dan jangka panjang, termasuk perilaku seksual berisiko. HBM juga sering digunakan sebagai kerangka berpikir pendidikan kesehatan, termasuk di dalamnya pendidikan seksualitas (Glanz \& Bishop, 2010).

HBM memiliki konsep utama yang dapat membentuk perilaku seseorang melakukan pencegahan, mendeteksi, atau mengontrol suatu kondisi penyakit. Konsep ini termasuk persepsi kerentanan terhadap suatu penyakit (perceived susceptibility), keseriusan/keparahan dampak dari suatu penyakit (perceived severity), manfaat akan suatu perilaku kesehatan yang akan diambil (perceived benefit), dan hambatan dalam melakukan perilaku kesehatan tersebut (perceived barrier). Jika masyarakat mempersepsikan mereka rentan terhadap suatu kondisi penyakit, percaya bahwa kondisi tersebut memiliki konsekuensi serius, percaya bahwa terdapat serangkaian langkah/tindakan menguntungkan yang dapat dilakukan untuk menurunkan kerentanan atau keseriusan suatu kondisi, dan percaya bahwa keuntungan tersebut melebihi hambatannya, maka mereka kemungkinan akan mengambil tindakan perilaku kesehatan yang dipercaya dapat mengurangi resiko tersebut (Glanz, Rimer, \& Viswanath, 2008).

Konsep tambahan dalam HBM adalah cues to Action dan self-efficacy. Cues to action adalah kejadian, orang, atau sesuatu yang menggerakkan individu merubah perilakunya, secara internal maupun eksternal. Misalnya nasihat dari orang yang kompeten, kampanye kesehatan di media, atau penyakit yang dimiliki oleh keluarga (pengalaman individu). Self-efficacy adalah konsep yang berasal dari Albert Bandura, yaitu keyakinan individu dapat melakukan suatu perilaku kesehatan dengan sukses. Individu biasanya tidak mencoba melakukan perilaku baru jika tidak yakin dirinya mampu. Keduanya ditambahkan ke dalam konsep HBM sebagai variabel yang terpisah (Glanz, Rimer, \& Viswanath, 2008).

Konsep HBM ini dianggap tepat dan lengkap dalam menggambarkan persepsi guru TK akan pendidikan seksual anak usia dini. Penelitian diambil di Taman Kanak-kanak Islam (TKI) XYZ dengan mempertimbangkan berbagai alasan. Berdasarkan wawancara pendahuluan 
terdapat fakta bahwa guru-guru TKI XYZ menyadari bahwa siswanya sekarang ini lebih kritis dan berani mengekspresikan sesuatu. Salah satunya yang beraitan dengan pertemanan dengan lawan jenis atau mengeksplorasi alat kelaminnya. Siswa pernah mempertanyakan mengenai seksualitas (hamil, kelahiran, alat kelamin), menunjukkan perilaku seksual (menggesek-gesekkan alat kelaminnya, bercanda dengan menyentuh area pribadi temannya) karena ketidaktahuannya, atau berteman dengan lawan jenis secara kurang sesuai (mencium, bergandengan tangan karena menganggap pacar) untuk usianya. Guru sebetulnya memiliki kekhawatiran terhadap perilaku siswanya tersebut, namun belum terpikirkan untuk menerapkan pendidikan seksual anak usia dini secara komprehensif kepada siswanya. Padahal anak usia dini termasuk kelompok yang rentan akan kekerasan seksual. Dengan mengacu pada pemaparan latar belakang diatas, maka fokus penelitianini adalah untuk mendeskripsikan persepsi guru TKI XYZ terhadap pendidikan seksual anak usia dini berdasarkan teori Health-Belief Model.

\section{METODE PENELITIAN}

Penelitian ini menggunakan pendekatan kuantitatifdan kualitatif. Instrumen penelitian kuantitatif berupa kuesioner. Kuesioner sudah melalui proses uji validitas dan reliabilitas. Uji validitas menggunakan content validity dan construct validity. Uji validitas content validity dilakukan dengan metode expert judgement. Pada tahap construct validity, dilakukan proses analisis item dengan teknik korelasi Pearson. Uji reliabilitas menggunakan metode cronbach's coefficient alpha, yang menunjukkan hasil masing-masing variabel penelitian reliabel.

Kuesioner terbagi menjadi tiga bagian. Bagian pertama terdiri dari 69 pernyataan mengukur lima variabel persepsi guru sesuai teori Health-Belief Model (HBM), yaitu Perceived Susceptibility, Perceived Severity, Perceived Benefit, Perceived Barrier, dan
Cues to Action. Setiap pernyataan memiliki empat alternatif jawaban yang terdiri dari "Sangat Setuju", "Setuju", "Tidak Setuju", dan "Sangat Tidak Setuju".

Bagian kedua terdiri dari 23 pernyataan mengukur variabel keenam dari teori HBM, yaitu Self-Efficacy. Setiap pernyataan juga memiliki empat alternatif jawaban yang terdiri dari "Sangat Percaya Diri", "Percaya Diri", "Kurang Percaya Diri", dan "Tidak Percaya Diri". Bagian ketiga terdiri dari 23 pernyataan mengukur Perilaku Kesehatan, yaitu penerapan pendidikan seksual anak usia dini yang sudah pernah dilakukan oleh guru. Setiap pernyataan memiliki empat alternatif jawaban yang terdiri dari "Sering", "Kadang-kadang", "Jarang”, dan "Tidak Pernah".

Instrumen penelitian kualitatif menggunakan teknik wawancara semi terstruktur dengan kerangka berpikir teori HBM. Teknik ini digunakan agar diperoleh data sesuai kerangka berpikir sesuai tujuan penelitian, namun wawancara dapat berkembang sesuai jawaban dari partisipan penelitian (Creswell, 2009). Pemilihan partisipan untuk wawancara adalah berdasarkan hasil data kuantitatif pada variabel Perilaku Kesehatan, yaitu masingmasing perwakilan guru dari tiap klasifikasi tinggi, sedang, dan rendah.

Teknik analisis data yang dilakukan dalam penelitian ini adalah teknik analisis data kuantitatif dan kualitatif. Data kuantitatif diolah melalui metode statistik deskriptif dan uji korelasi Pearson. Analisis data kualitatif dilakukan melalui coding dan content analysis. Penentuan partisipan penelitian menggunakan teknik purposive sampling, yaitu teknik pemilihan partisipan berdasarkan karakteristik tertentu (Berg, 2007). Partisipan penelitian adalah sumber data terbaik untuk mencapai tujuan penelitian, maka partisipan penelitian yang memenuhi karakteristik tersebut adalah seluruh guru yang mengajar di TK XYZ, yaitu enam belas orang guru. 


\section{PEMBAHASAN}

Hasil Penelitian

$\begin{array}{ccc}\text { Uji } & \text { normalitas dilakukan } \\ \text { mengunakan } & \text { metode } & \text { Kolmogorov- }\end{array}$ Smirnov. Hasil uji normalitas, seperti yang terlihat pada Tabel 1, menunjukkan bahwa data dalam setiap variabel Health-Belief Model (HBM) berada dalam distribusi normal. Oleh karena itu, metode statistik parametrik dapat digunakan dalam analisis data kuantitatif yaitu uji korelasi Pearson. Hasil uji korelasi Pearson dipaparkan pada Tabel 2. Pada tabel ini setiap variabel diberi label, yaitu SUS untuk Perceived Susceptibility, SEV untuk Perceived Severity, BEN untuk Perceived Benefit, BAR untuk Perceived Barrier, CUE untuk Cues to Action, SE untuk Self-Efficacy, dan PK untuk Perilaku Kesehatan.
Tabel 1. Hasil Uji Normalitas KolmogorovSmirnov

\begin{tabular}{lcc}
\hline \multicolumn{1}{c}{ Variabel } & $\underline{\mathrm{Z}}$ & $\mathrm{p}$ \\
\cline { 1 - 2 } $\begin{array}{l}\text { Perceived } \\
\begin{array}{l}\text { Susceptibility } \\
(\mathrm{n}=16)\end{array}\end{array}$ & .653 & $.787^{*}$ \\
$\begin{array}{l}\text { Perceived Severity } \\
(\mathrm{n}=16)\end{array}$ & .813 & $.523^{*}$ \\
$\begin{array}{l}\text { Perceived Benefit } \\
(\mathrm{n}=16)\end{array}$ & .892 & $.404^{*}$ \\
$\begin{array}{l}\text { Perceived Barrier } \\
(\mathrm{n}=16)\end{array}$ & .625 & $.830^{*}$ \\
$\begin{array}{l}\text { Cues to Action } \\
(\mathrm{n}=16)\end{array}$ & 1.250 & $.088^{*}$ \\
$\begin{array}{l}\text { Self Efficacy } \\
(\mathrm{n}=16)\end{array}$ & .853 & $.461^{*}$ \\
$\begin{array}{l}\text { Perilaku Kesehatan } \\
(\mathrm{n}=16)\end{array}$ & .981 & $.291^{*}$ \\
\hline
\end{tabular}

$* \mathrm{p}>.05$

Tabel 2. Hasil Uji Korelasi Pearson antar Variabel Persepsi dan Perilaku Kesehatan Guru

\begin{tabular}{|c|c|c|c|c|c|c|c|c|}
\hline \multicolumn{2}{|c|}{ Variabel } & 1 & 2 & 3 & 4 & 5 & 6 & 7 \\
\hline $\begin{array}{l}\text { 1. SU } \\
\mathrm{S}\end{array}$ & $r$ & 1 & $.6{ }^{83^{*}}$ & $.568^{*}$ & $.576 * *$ & .367 & .139 & .451 \\
\hline & $\mathrm{p}$ & & .004 & .022 & .019 & .162 & .607 & .080 \\
\hline $\begin{array}{l}\text { 2. SE } \\
\mathrm{V}\end{array}$ & $\mathrm{r}$ & $.683 * *$ & 1 & $.706 * *$ & ${ }^{-}-$ & .391 & -..046 & $.533 *$ \\
\hline & $\mathrm{p}$ & .004 & & .002 & .001 & .134 & .866 & .033 \\
\hline $\begin{array}{c}\text { 3. } \mathrm{BE} \\
\mathrm{N}\end{array}$ & $\mathrm{r}$ & $.568 *$ & $\begin{array}{c}.706^{*} \\
*\end{array}$ & 1 & $\begin{array}{c}- \\
.771^{* *}\end{array}$ & $\begin{array}{c}.7^{84 *} \\
*\end{array}$ & .445 & $6_{08} *$ \\
\hline & $\mathrm{p}$ & .022 & .002 & & .000 & .000 & .084 & .012 \\
\hline $\begin{array}{c}\text { 4. BA } \\
\text { R }\end{array}$ & $\mathrm{r}$ & $\begin{array}{c}- \\
.576^{* *}\end{array}$ & $\begin{array}{c}7_{33 *}^{-} \\
*\end{array}$ & $\begin{array}{c}- \\
771 * *\end{array}$ & 1 & -.342 & -.322 & $.573 *$ \\
\hline & $\mathrm{p}$ & .019 & .001 & .000 & & .194 & .223 & .020 \\
\hline $\begin{array}{c}\text { 5. CU } \\
\mathrm{E}\end{array}$ & $\mathrm{r}$ & 367 & .391 & $.784 * *$ & -.342 & 1 & $\begin{array}{c}.539 \\
*\end{array}$ & .361 \\
\hline & $\mathrm{p}$ & .162 & .134 & .000 & .194 & & .031 & .169 \\
\hline 6. SE & $\mathrm{r}$ & .139 & -.046 & .445 & -.322 & $.539 *$ & 1 & .058 \\
\hline & $\mathrm{p}$ & .607 & .866 & .084 & .223 & .031 & & .830 \\
\hline 7. PK & $\mathrm{r}$ & .451 & $.533^{*}$ & $608^{*}$ &.$- .73^{*}$ & .361 & .058 & 1 \\
\hline & $\mathrm{p}$ & .080 & .033 & .012 & .020 & .169 & .830 & \\
\hline
\end{tabular}

$$
\begin{aligned}
& * \mathrm{p}<.05 \\
& * * \mathrm{p}<.01
\end{aligned}
$$

Pada hasil tersebut terlihat bahwa antara keempat variabel utama dalam HBM menunjukkan adanya hubungan yang signifikan kuat dan positif, kecuali Perceived Barrier yang hubungannya signifikan kuat dan negatif. Perilaku Kesehatan juga menunjukkan hubungan signifikan yang kuat dengan Perceived
Severity $(r=.533 ; p<.05)$, Perceived Benefit $(\mathrm{r}=.608 ; \mathrm{p}<.05)$, dan Perceived Barrier $(\mathrm{r}=.573 ; \mathrm{p}<.05)$. Korelasi yang kuat dan positif ini menunjukkan jika terjadi peningkatan maupun penurunan pada salah satu variabel maka akan mempengaruhi peningkatan maupun penurunan pada variabel lainnya. 
Variabel tambahan dalam HBM, yaitu Cues to Action dan Self-Efficacy nampak tidak memiliki hubungan signifikan dengan Perilaku Kesehatan, namun kedua variabel ini memiliki hubungan kuat dan positif satu sama lain $(\mathrm{r}=.539 ; \mathrm{p}<.05)$. Cues to Action juga terlihat memiliki hubungan signifikan sangat kuat dan positif dengan Perceived Benefit $(\mathrm{r}=.784 ; \mathrm{p}<.05)$. Artinya jika variabel Cues to Action mengalami peningkatan maupun penurunan maka akan mempengaruhi peningkatan maupun penurunan pada variabel Perceived Benefit.

Selanjutnya, dalam data deskriptif klasifikasi untuk masing-masing variabel HBM dibagi menjadi tiga bagian, yaitu tinggi, sedang, dan rendah. Peneliti membuat cut points berdasarkan perhitungan mean dan standard deviation. Hasil perhitungan tersebut dapat dilihat pada Tabel 3.

Tabel 3. Klasifikasi Tingkat Persepsi dan Tingkat Frekuensi Perilaku Kesehatan Guru berdasarkan HealthBelief Model

\begin{tabular}{|c|c|c|}
\hline Kategori Skor & $\begin{array}{l}\text { Frekuens } \\
\mathrm{i}(\mathrm{n}=16)\end{array}$ & $\begin{array}{c}\text { Persentase } \\
(\%)\end{array}$ \\
\hline \multicolumn{3}{|l|}{ Perceived } \\
\hline \multicolumn{3}{|l|}{ Susceptibility } \\
\hline Rendah $(\leq 28)$ & 3 & 18.75 \\
\hline Sedang (29-35) & 8 & 50 \\
\hline Tinggi $(\geq 36)$ & 5 & 31.25 \\
\hline \multicolumn{3}{|l|}{ Perceived Severity } \\
\hline Rendah $(\leq 58)$ & 3 & 18.75 \\
\hline Sedang (59-72) & 10 & 62.5 \\
\hline Tinggi $(\geq 73)$ & 3 & 18.75 \\
\hline \multicolumn{3}{|l|}{ Perceived Benefit } \\
\hline Rendah $(\leq 42)$ & 3 & 18.75 \\
\hline Sedang (43-48) & 10 & 62.5 \\
\hline Tinggi $(\geq 49)$ & 3 & 18.75 \\
\hline \multicolumn{3}{|l|}{ Perceived Barrier } \\
\hline Rendah $(\leq 23)$ & 2 & 12.5 \\
\hline Sedang (24-29) & 11 & 68.75 \\
\hline Tinggi $(\geq 30)$ & 3 & 18.75 \\
\hline \multicolumn{3}{|l|}{ Cues to Action } \\
\hline Rendah $(\leq 25)$ & 4 & 25 \\
\hline Sedang (24-28) & 10 & 62.5 \\
\hline Tinggi $(\geq 29)$ & 2 & 12.5 \\
\hline
\end{tabular}

$\begin{array}{lcc}\text { Self Efficacy } & & \\ \text { Rendah }(\leq 60) & 1 & 6.25 \\ \text { Sedang }(61-74) & 13 & 81.25 \\ \text { Tinggi }(\geq 75) & 2 & 12.5\end{array}$

Perilaku

Kesehatan

Rendah $(\leq 66) \quad 4 \quad 25$

Sedang (65-76) $\quad 9 \quad 56.25$

Tinggi $(\geq 77) \quad 3 \quad 18.75$

Pemahaman dari klasifikasi tinggi dalam variabel Perceived Susceptibility, Perceived Severity, Perceived Benefit, Perceived Barrier, Cues to Action, dan Self Efficacy adalah partisipan memiliki persepsi atau keyakinan yang cenderung positif. Klasifikasi sedang memiliki pemahaman partisipan memiliki persepsi atau keyakinan yang cenderung netral, sedangkan klasifikasi rendah partisipan memiliki persepsi atau keyakinan yang cenderung rendah. Pemahaman klasifikasi untuk Perilaku Kesehatan adalah sering untuk klasifikasi tinggi, cukup untuk klasifikasi sedang, dan jarang atau tidak pernah untuk klasifikasi rendah.

Pada variabel Perceived Susceptibility sebagian besar guru (50\%) TKI XYZ mempersepsikan kerentanan siswanya pada tingkatan sedang atau cenderung netral, ada 5 orang guru $(31.25 \%)$ yang mempersepsikan secara tinggi atau positif, namun masih ada juga 3 orang guru $(18.75 \%)$ yang mempersepsikan kerentanan siswanya terhadap kekerasan seksual secara rendah atau cenderung negatif. Variabel Perceived Severity menunjukkan sebagian besar guru (62.5\%) mempersepsikan keseriusan dampak dari kekerasan seksual anak usia dini pada tingkatan sedang atau cenderung netral. Ada 3 orang guru (18.75\%) mempersepsikan hal tersebut pada tingkatan tinggi atau cenderung positif, namun masih ada juga 3 orang guru lagi $(18.75 \%)$ yang mempersepsikannya pada tingkatan rendah atau cenderung negatif.

Pada variabel manfaat akan pendidikan seksual anak usia dini atau Perceived Benefit terlihat bahwa 10 orang guru $(62.5 \%)$ 
mempersepsikannya pada tingkatan sedang atau netral. Ada 3 orang guru (18.75\%) mempersepsikan manfaat pendidikan seksual bagi siswanya tersebut pada tingkatan tinggi atau cenderung positif, namun masih ada juga 3 orang guru (18.75\%) yang mempersepsikannya pada tingkatan rendah atau cenderung negatif. Variabel Perceived Barrier menunjukkan bahwa 11 orang guru (68.75\%) mempersepsikan hambatan dalam menerapkan pendidikan seksual anak usia dini pada tingkatan sedang atau cenderung netral. Ada 3 orang guru (18.75\%) yang mempersepsikannya pada tingkatan tinggi atau cenderung positif, namun masih ada juga 2 orang guru (12.5\%) yang mempersepsikannya secara negatif.

Variabel Cues to Action juga cukup bervariasi, nampak 10 orang guru $(62.5 \%)$ mempersepsikan sumber informasi eksternal dan internal yang dapat membantunya menjalankan pendidikan seksual anak usia dini pada tingkatan sedang atau cenderung netral. Ada juga 2 orang guru $(12.5 \%)$ yang memiliki persepsi pada tingkatan tinggi atau cenderung positif, namun masih ada 4 orang guru $(25 \%)$ yang mempersepsikannya pada tingkatan rendah atau cenderung negatif. Dalam variabel Self-Efficacy dapat terlihat sebagian besar guru (81.25\%) mempersepsikan kemampuan dirinya dalam mengajar pendidikan seksual anak usia dini pada siswanya secara netral atau pada tingkatan sedang. Ada 2 orang guru (12.5\%) yang mempersepsikannya pada tingkatan tinggi atau positif, namun masih ada juga 1 orang guru (6.25\%) yang mempersepsikannya secara negatif atau rendah. Variabel Perilaku Kesehatan menunjukkan 9 orang guru $(56.25 \%)$ merasa cukup atau pada tingkatan sedang dalam menerapkan pendidikan seksual anak usia dini pada siswanya. Ada 3 orang guru $(18.75 \%)$ merasa telah sering menerapkan pendidikan seksual pada siswanya, namun masih ada 4 orang guru (25\%) yang merasa jarang melakukan hal tersebut.

Dari data kualitatif dengan metode wawancara tergambarkan bahwa guru-guru TKI XYZ belum menerapkan pendidikan seksual anak usia dini secara komprehensif pada siswanya, meskipun dalam klasifikasi variabel Perilaku Kesehatan sebagian besar guru merasa telah cukup mengajarkan pendidikan seksual anak usia dini. Hal ini disebabkan persepsi guru yang merasa sudah memberikan informasi atau mengajarkan pendidikan seksual padahal hal tersebut baru dilakukannya sesekali. Selain itu, informasi yang disampaikan kepada siswa tidak terencana/tidak sistematis, bersifat situasional tergantung kejadian, belum merata pada seluruh siswa, sehingga belum dapat di evaluasi keefektifannya.

Pada variabel Perceived Susceptibility, Perceived Severity, Perceived Benefit, dan Perceived Barrier, terlihat bahwa pemahaman guru TKI XYZ akan kekerasan seksual anak usia dini cenderung kurang akurat. Guru merasa siswanya rentan akan kekerasan seksual, namun meyakini bahwa kekerasan seksual tidak mungkin terjadi di sekolah karena penjagaan yang ketat. Guru juga belum memahami perannya dan manfaat dalam menerapkan pendidikan seksual anak usia dini secara komprehensif. Hal ini disebabkan pengetahuan guru belum menyeluruh akan kekerasan seksual, perkembangan seksual, dan pendidikan seksual anak usia dini. Hambatan yang dirasakan guru dalam menerapkan pendidikan seksual adalah kemampuan dirinya, persetujuan orangtua siswa, dan rasa tabu dalam mengucapkan istilah-istilah yang berhubungan dengan seksualitas (seperti "vagina", "penis").

Variabel Cues to Action menunjukkan bahwa guru TKI XYZ sumber informasi mengenai kekerasan seksual dan pendidikan seksual anak usia dini termasuk minim. Guru-guru belum pernah mengikuti pelatihan ataupun memiliki pengalaman terkait hal tersebut. Guru hanya mengandalkan pelatihan, kebijakan, dan sumber informasi dari sekolah sebagai dasar pengetahuannya. Sedangkan dalam variabel Self-Efficacy, guru sebenarnya merasa kurang percaya diri akan kemampuannya mengajarkan materi pendidikan seksual anak usia dini. Akan tetapi, guru merasa percaya diri dalam 
menghadapi dan menangani siswanya sendiri dengan latar belakang pengalaman yang ia miliki selama mengajar di TKI XYZ.

\section{Pembahasan}

Pada hasil penelitian terlihat bahwa gambaran Perilaku Kesehatan berupa penerapan pendidikan seksual anak usia dini yang dilakukan guru terhadap siswanya belum dilakukan secara komprehensif, karena sifatnya hanya situasional, tidak terencana/tidak sistematis, sehingga belum merata pada seluruh siswa. Gambaran perilaku ini berkaitan dengan persepsi guru terhadap pendidikan seksual anak usia dini, dimana faktor pengetahuan dan pengalaman guru guru merupakan indikator yang kuat dalam mempengaruhi persepsi guru itu sendiri (Safitri \& Mahmudah, 2015).

Penelitian terdahulu yang dilakukan Safitri dan Mahmudah (2015) menyebutkan bahwa guru TK memiliki persepsi positif terhadap pendidikan seksual anak usia dini disebabkan oleh pengetahuan dasar yang cukup dan pengalaman menghadapi perilaku seksual yang telah sesuai dengan teori. Dalam penelitian ini lamanya pengalaman guru bekerja nampak tidak berhubungan dengan persepsi guru terhadap pendidikan seksual anak usia dini. Hal ini berkaitan dengan pengetahuan dan pemahaman guru TKI XYZ yang kurang akan perannya dan manfaat dalam menerapkan pendidikan seksual anak usia dini secara komprehensif. Mayoritas guru-guru TKI XYZ belum memandang positif pendidikan seksual anak usia dini. Pada semua variabel persepsi guru, sesuai teori Health-Belief Model (HBM), mayoritas guru berada pada klasifikasi tingkat persepsi sedang atau netral. Ada sebagian guru yang memandang positif, namun masih ada juga yang memandang negatif pendidikan seksual anak usia dini.

Persepsi guru cenderung netral dalam tiap variabel HBM, artinya guruguru TKI XYZ sebetulnya cukup meyakini siswanya rentan akan kekerasan seksual dan keseriusan dampak dari kekerasan seksual itu sendiri. Guru-guru juga cukup meyakini manfaat pendidikan seksual dan di sisi lain juga cukup meyakini hambatanhambatan yang dirasakan dalam menerapkan pendidikan seksual anak usia dini. Selain itu, guru-guru juga cukup meyakini sumber informasi eksternal yang dapat menunjangnya melakukan pendidikan seksual serta memiliki cukup keyakinan diri akan kemampuannya melakukan hal tersebut. Akan tetapi, keyakinan yang cukup tersebut kurang kuat untuk guru-guru melakukan pendidikan seksual anak usia dini terhadap siswanya. Berdasarkan teori HBM, hal ini disebabkan pengetahuan guru akan kekerasan seksual, perkembangan seksual, dan pendidikan seksual anak usia dini belum menyeluruh, sehingga pemahaman guru pun menjadi kurang akurat. Selain itu, ada juga faktor budaya yang mempengaruhi persepsi guru. Pengetahuan dan budaya ini dalam teori HBM termasuk Modifying Factors. Tingkat pengalaman dan usia guru yang bervariasi nampak tidak terlalu mempengaruhi perbedaan persepsi guru. Di TKI XYZ tingkat pendidikan dan jenis kelamin guru tidak bervariasi, yaitu semuanya $\mathrm{S} 1$ dan berjenis kelamin perempuan. TKI XYZ merupakan sekolah beragama Islam. Hal ini merupakan prinsip dasar di TKI XYZ, suatu pendidikan berdasarkan agama lebih dapat diterima oleh guru-guru di TKI XYZ. Hal ini dapat menjadi pertimbangan dalam memberikan intervensi, seperti misalnya menggunakan model pendidikan seksual anak usia dini persepktif gender dalam penelitian sebelumnya yang mengandung nilai-nilai Islami (Jatmikowati, Angin, \& Ernawati, 2015).

Variabel-variabel utama dalam HBM seperti Perceived Susceptibility, Perceived Severity, Perceived Benefit, Perceived Barrier, berdasarkan hasil uji korelasi antar variabel terlihat saling berkorelasi secara kuat dan berkorelasi juga dengan Perilaku Kesehatan. Perceived Severity dan Perceived Benefit memiliki hubungan 
yang signifikan kuat dan positif dengan Perilaku Kesehatan. Perceived Barrier memiliki hubungan yang signifikan kuat dan negatif dengan Perilaku Kesehatan. Hal ini sesuai dengan teori HBM yang digunakan. Dalam teori HBM, Perceived Susceptibility dikombinasikan dengan Perceived Severity untuk membentuk Perceived Threat yang mempengaruhi Perilaku Kesehatan. Perceived Susceptibility memang memiliki hubungan yang signifikan kuat dan positif dengan Perceived Severity, namun Perceived Susceptibility tidak berkorelasi dengan Perilaku Kesehatan. Artinya, persepsi guru TKI XYZ akan kerentanan siswanya terhadap kekerasan seksual tidak berhubungan dengan Perilaku Kesehatan yang dilakukan guru berupa penerapan pendidikan seksual anak usia dini pada siswanya. Jika melihat data kualitatif, penjelasan akan hal ini adalah guru-guru TKI XYZ memandang siswanya cukup rentan akan kekerasan seksual, akan tetapi guru juga beranggapan bahwa kecil kemungkinan kekerasan seksual terjadi di sekolah karena penjagaan yang memadai dan selama ini belum pernah terjadi kekerasan seksual di sekolah.

Berdasarkan penelitian terdahulu, Perceived Susceptibility memang tidak selalu mengarahkan individu untuk membentuk perilaku kesehatan, karena berkaitan juga dengan pengalaman individu terhadap kondisi tersebut (Carpenter, 2010). Individu yang pernah mengalami langsung menjadi korban kekerasan seksual atau pernah menyaksikan kekerasan seksual anak usia dini kemungkinan besar memiliki Perceived Susceptibility yang tinggi dan terdorong untuk mencari tahu atau melakukan Perilaku Kesehatan. Dalam konteks penelitian ini, guru memang belum pernah mengalami langsung atau menyaksikan langsung kekerasan seksual pada siswanya. Apalagi guru merasa kecil kemungkinan hal tersebut terjadi di sekolah.
Variabel lain yang tidak berhubungan dengan Perilaku Kesehatan adalah Cues to Action. Artinya, tingkat keyakinan guru TKI XYZ terhadap berbagai informasi eksternal (buku, artikel, seminar, pelatihan) dan internal (pengalaman guru) mengenai kekerasan seksual anak usia dini tidak berhubungan dengan Perilaku Kesehatan yang dilakukan guru berupa penerapan pendidikan seksual anak usia dini pada siswanya. Pada dasarnya, berdasarkan hasil wawancara, guru-guru TKI XYZ kurang terpapar akan berita dan informasi mengenai kekerasan seksual maupun pendidikan seksual anak usia dini. Informasi-informasi yang guru miliki nampak hanya bersumber dari sekolah. Artikel kekerasan seksual yang menjadi sumber guru-guru merupakan kejadian beberapa tahun lalu yang pada akhirnya memang menjadi bahan diskusi di sekolah dan membuat perubahan kebijakan di sekolah, yaitu adanya penambahan office girl di toilet sekolah. Guru-guru juga belum pernah mengikuti pelatihan selain yang diberikan oleh yayasan di sekolah. Pelatihan pendidikan seksual anak usia dini belum pernah diikuti dan belum menjadi minat sebagian besar guru untuk mencari tahu.

Variabel terakhir yang tidak berkorelasi dengan Perilaku Kesehatan adalah Self Efficacy. Artinya, tingkat keyakinan guru TKI XYZ akan kemampuan dirinya mengajar pendidikan seksual anak usia dini tidak berhubungan dengan Perilaku Kesehatan yang dilakukan guru terhadap siswanya. Hasil data kuantitatif untuk variabel Self Effficacy menunjukkan hampir tidak ada guru TKI $\mathrm{XYZ}$ yang merasa kurang percaya diri dalam mengajar materi pendidikan seksual anak usia dini. Akan tetapi, berdasarkan hasil wawancara, guru-guru mengakui sebetulnya ada rasa kurang percaya diri dan kurang meyakini cara yang sudah dilakukannya selama ini. Dalam mengisi kuesioner, guru-guru menyebutkan merasa percaya diri karena merasa sudah sangat mengenal siswa-siswanya, sehingga 
mengajar materi apapun guru merasa mampu dengan caranya sendiri. Guru merasa pasti bisa 'mengatasi' sikap atau pertanyaan-pertanyaan dari siswa meskipun pengetahuan guru terbatas. Kedua variabel terakhir ini, Cues to Action dan Self-Efficacy memang merupakan variabel tambahan dalam HBM. Penelitian meta-analisis yang dilakukan oleh Carpenter (2010) tidak mengikutsertakan penelitian yang menggunakan kedua variabel tambahan ini, karena jarang digunakan dalam penelitian dan dianggap kurang dikembangkan sebagai elemen dalam HBM dan tidak selalu berhubungan dengan Perilaku Kesehatan.

Terdapat beberapa keterbatasan dalam penelitian ini. Pertama, peneliti tidak menggunakan HBM untuk melihat variabel-variabel persepsi sebagai prediktor dari perilaku, akan tetapi sebagai gambaran persepsi dan hubungannya dengan perilaku untuk memetakan kebutuhan guru dalam menerapkan suatu perilaku kesehatan. Hal ini disebabkan secara kuantitas, jumlah guru terlalu sedikit untuk menerapkan sebuah model teori, sehingga dikhawatirkan hasilnya tidak menggambarkan kebutuhan guru yang sebenarnya. Kedua, penelitian HBM mengenai pendidikan seksual masih sangat jarang ditemukan, khususnya di Indonesia. Peneliti menemukan sejumlah penelitian terkait pendidikan seksual yang menggunakan HBM, beberapa tidak menggunakan keempat variabel utama HBM, namun hanya Perceived Benefit dan Perceived Barrier yang kemudian diteliti bersamaan dengan variabel-variabel dari teori lain. Pada awalnya, Rosenstock (dalam Glanz, Rimer, \& Viswanath, 2008) mengembangkan Health-Belief Model untuk memprediksi perilaku individu dalam mencegah atau mengatasi penyakit kesehatan yang fokusnya pada kondisi fisik individu. Sedangkan dalam penelitian ini, pendidikan seksual anak usia dini adalah pendidikan kesehatan yang fokusnya sebagai pencegahan dari penyakit yang berdampak tidak hanya secara fisik, namun juga secara psikologis.

Keterbatasan ketiga adalah terkait dengan subyek penelitian. Hampir semua penelitian terdahulu yang menggunakan Health-Belief Model meneliti mengenai persepsi individu yang berhubungan langsung dengan dirinya dan perilaku yang ditargetkan juga bagi dirinya sendiri. Misalnya penelitian mengenai target perilaku wanita yang melakukan mamografi, maka yang digali adalah persepsi wanita akan kerentanan dirinya dan keseriusan dampak dari kanker payudara, persepsi manfaat dan hambatan yang dirasakan dalam menjalani program mamografi. Penelitian tersebut subyeknya adalah wanita pelaku langsung terhadap

target perilaku yang diukur dan persepsinya terhadap dirinya sendiri dalam kaitannya melakukan target perilaku (Carpenter, 2010). Sedangkan dalam penelitian ini, guru memang orang yang melakukan target perilaku, namun menjadi pihak kedua sebagai perantara informasi

kebutuhan siswanya. Dampak dari penerapan perilaku tidak secara langsung dirasakan manfaatnya oleh guru, sehingga persepsinya pun kemungkinan menjadi kurang kuat.

\section{PENUTUP}

Guru TKI XYZ belum melakukan Perilaku Kesehatan berupa pendidikan seksual anak usia dini secara komprehensif pada siswanya karena sebagian besar guruguru belum memandang secara positif pendidikan seksual anak usia dini. Persepsi guru ini dilatarbelakangi oleh faktor pengetahuan dan pemahaman guru yang kurang akurat.

Guru belum memahami perannya dalam penerapan pendidikan seksual anak usia dini dan manfaatnya bagi siswa secara komprehensif, karena pengetahuan guru juga kurang menyeluruh. Selain itu, terdapat hambatan berupa persetujuan orangtua siswa dan rasa tabu dalam menerapkan pendidikan seksual. Oleh karena itu, guru perlu diberikan pelatihan 
untuk meningkatkan pemahamannya akan perannya dalam menerapkan pendidikan seksual dan memahami perkembangan seksual anak usia dini, sehingga memahami juga cara penyampaian yang tepat kepada siswanya. Sebuah modul pelatihan guru telah dibuat untuk diterapkan mengenai pendidikan seksual anak usia dini untuk TKI XYZ.

TKI XYZ berlandaskan agama Islam dan lebih dapat menerima pendidikan yang berdasarkan agama Islam. Pembahasaan pendidikan seksual pun menjadi lebih dapat diterima ketika diubah menjadi pendidikan reproduksi. Oleh karena itu, dalam modul pelatihan, pendidikan seksual anak usia dini disebut dengan pendidikan reproduksi dan semua materi diintegrasikan dengan nilai-nilai agama Islam.

TKI XYZ juga dapat meningkatkan pengetahuan guru mengenai pendidikan seksual anak usia dini. Misalnya dengan memperbanyak buku-buku perpustakaan yang memfasilitasi kebutuhan guru. Dapat juga dengan berlangganan media seperti koran, majalah yang berhubungan dengan pendidikan atau media digital dengan mengoptimalkan fasilitas penggunaan internet di sekolah.

\section{UCAPAN TERIMA KASIH}

Artikel ini disarikan dari tesis yang berjudul "Persepsi Guru TK terhadap Pendidikan Seksual Anak Usia Dini berdasarkan HealthBelief Model". Oleh karena itu, peneliti ucapkan terima kasih kepada semua pihak yang membantu terwujudnya tesis ini.

\section{DAFTAR PUSTAKA}

Berg, B.L. (2007). Qualitative research methods for the social sciences. $\left(6^{\text {th }}\right.$ Ed). Boston, MA: Pearson Education, Inc.

Brewer, N. T., \& Rimer, B. K. (2008). Health behavior and health education: theory, research, and practice. $4^{\text {th }} \mathrm{Ed}$.
Carpenter, C. J. (2010). A meta-analysis of the effectiveness of health belief model variables in predicting behavior. Journal of Health Communication, 25 (8), 661-669

Christianti, M. (2012). Profesionalisme pendidik anak usia dini. Jurnal Pendidikan Anak, 1 (1), 112-122

Conner, M. (2002). Health behaviors. UK: University of Leeds

Creswell, J. W. (2009). Research design: qualitative, quantitative, and mixed methods approaches $\left(3^{\text {rd }} e d\right)$. London: SAGE Publications

Glanz, K., \& Bishop, D. B. (2010). The role of behavioral science theory in development and implementation of public health interventions. Journal of Annual Review Public Health, 31, 399-418

Glanz, K., Rimer, B. K., \& Viswanath, K. (2008). Health behavior and health education: theory, research, and practice. $4^{\text {th }}$ Ed. San Fransisco: Jossey-Bass, A Wiley Imprint

Hapsari, M. I. (2016). Penerapan pendidikan seks di PAUD (kelompok bermain dan taman kanak-kanak) sebagai upaya pencegahan dan penanganan perilaku seksual yang bermasalah pada anak. Makalah disampaikan dalam Seminar Nasional: Parenting and Education About Sex. Purwokerto, 26 Oktober 2016

Hastuti, S. (2014). Pendidikan seksual anak di TK dan SD: sebuah interaksi pelayanan bimbingan. Makalah disampaikan dalam Seminar Sanata Dharma Berbagi "Pendidikan Seksual Anak di Masa Sekolah Awal. Yogyakarta, 8 September 2014 
Humaira, D., Rohmah, N., Rifanda, N., Novitasari, K., Diena, U., \& Nuqul, F.L. (2015). Kekerasan seksual pada anak: telaah relasi pelaku korban dan kerentanan pada anak. Jurnal Psikologi Islam, Vol. 12 (2), $5-10$

Jatmikowati, T. E., Angin, R., \& Ernawati. (2015). Model dan materi pendidikan seks anak usia dini perspektif gender untuk menghindarkan sexual abuse. Cakrawala Pendidikan, XXXIV (3), 434-448

Justicia, R. (2016). Program underwear rules untuk mencegah kekerasan seksual pada anak usia dini. Jurnal Pendidikan Usia Dini, 9 (2), 217 232

Yulianti, P. D., \& Handayani, A. (2016). Peran guru dalam pendidikan seksualitas dan reproduksi bagi anak (prevensi kekerasan seksual anak). Eprints Universitas PGRI Semarang
Maslihah, S. (2013). Play therapy dalam identifikasi kasus kekerasan seksual terhadap anak. Jurnal Penelitian Psikologi, vol. 04, no. 01, hal. $21-34$

Safitri, D. G. L., \& Mahmudah, S. (2015). Persepsi guru taman kanak-kanak terhadap pendidikan seksual anak sia dini. Jurnal PAUD Teratai, 4 (2), 1-10

Salkind, N. J. (2008). Encyclopedia of educational psychology. California: Sage Publication, Inc.

Solihin, S. (2015). Pendidikan seks untuk anak usia dini. Jurnal pendidikan sekolah dasar, 1 (2), hal. 56-73

UNESCO. (2009). International technical guidance on sexuality education. Paris: Education Sector

WHO Regional Office for Europe. (2010). Standards for sexuality education on Europe. Cologne: Federal Center for Health Education. 